\title{
MEASURING THE IMPACT OF A COMMUNITY EXTENSION PROGRAM IN THE PHILIPPINES
}

\author{
${ }^{1}$ Ian Ibanez Llenares \& ${ }^{2}$ Custer Calingasan Deocaris \\ ${ }^{1}$ National University, Manila, Philippines \\ ${ }^{2}$ Technological Institute of the Philippines - Cubao \\ Quezon City, Philippines \& \\ De La Salle University, Manila, Philippines
}

Corresponding author: ianllenares8@national-u.edu.ph

Received: 30 November 2017

Accepted: 5 April 2018

\section{ABSTRACT}

Purpose - This study was designed to create platforms to train students in higher education to be caring and responsible citizens. This was an extension mission that aimed to tap into the expertise of academe and its knowledge to help the community. Based on the framework of academic of community empowerment, the researchers measured the long-term impact of a 44-month community extension program in the Philippines. The extension program described in this study was implemented between March 2009 and December 2015 to address the capacity-building needs of a low-income community. This paper highlights some key development activities which includes partnership with local government, training needs assessment through grassroots-level participation and design of practical education-training programs.

Methodology - The study followed a descriptive research design. The Community Outcome Scale (COS) was developed to measure perceived knowledge, attitude, and lifestyle of the beneficiaries. Fifty-four community residents were purposively selected based on their attendance to the community-based education and training programs. The ANOVA method with post hoc analysis was employed to determine the differences between perceived knowledge, attitude, and lifestyle among residents, stratified according to the degree of completion of the training programs. 
Findings - There was a moderate improvement in community knowledge, attitude, and lifestyle based on the survey which was performed one and a half years after the completion of the extension programs. Based on the results, improved long-term outcomes were noted only amongst the regular and occasional participants.

Significance - There is an increasing appreciation of the impact of higher education extension in the teaching and learning process as students apply their disciplinary knowledge to help address realworld problems. This work may be of interest to higher education institutions (HEIs) which are designing community extension programs with optimized societal outcomes.

Keywords: Community outreach, service learning, university extension, Philippine higher education system, experiential education.

\section{INTRODUCTION}

Ever-growing social inequities confront most low- and middleincome countries as many people still have insufficient access to proper education and training. This problem results in citizens who lack the necessary skills for employment or are disempowered to engage in entrepreneurial pursuits. As higher education institutions (HEIs) are concerned with delivering extension programs to reach development goals, it is paramount that academic institutions should also monitor and evaluate the outcomes of their community programs at the grassroots level.

In the Philippines, universities and colleges have been mandated by the Commission on Higher Education (CHED) to extend their educational and civic services to the community. An example of such policies is the Republic Act 9163, otherwise known as the "National Service Training Program (NSTP) Act of 2001", which highlights the commitment of HEIs to provide, promote and sustain community service. It is noteworthy to understand that is similar to the United States' community service-learning programs under the US National and Community Service Act of 1990 (Markus, Howard, \& King, 1993). Recently, the Commission has initiated efforts to re-direct 
extension programs under the CHED Memorandum Order 52, series of 2016. The policy provides some guidelines on HEI community extension programs for the "provision of space to discover practical, evidence- and science-based answers that can address real-world social, economic, and environmental challenges of partner citizens and communities." As producers of knowledge or hubs of innovations, the new extension policy posits that HEIs are in a strategic position to work in partnership with communities, business, and industry in facilitating the transfer of knowledge or technology on specific developmental areas. University extensions "or the "extensions of the universities" are "any educational innovations done outside the university" (Mounders, 1972). These innovations mainly focus on literary, agricultural and social topics.

Partnerships between HEIs and the community should be mutually beneficial. Research and technology-transfer activities by the academe should have the potential to improve curriculum and pedagogy. For students, extension programs help to instill the value of citizenship in a manner that traditional classroom teaching is unable to provide. Such engagements can also add new ideas and insights to the intellectual process and give broader meaning to the work and world of academics (Soska \& Butterfield, 2013). Concomitantly, community stakeholders gain more understanding of relevant issues and are empowered to make decisions to alleviate their present conditions.

The modalities of extension program delivery by HEIs vary. There are delivery methods that focus on involving students to assist local organizations and other methods that involve faculty and staff programs to address community development in the form of educational cohorts, social service, public health, and livelihood and technical training, consultations and direct application of R\&D output. The more common examples of extension activities are livelihood (Daquis, Flores, \& Plandez, 2016; Felicen, Mendoza, \& Buted, 2014; Peprah et al., 2017), health promotion (Daquis et al., 2016; O'loughlin et al., 1999; Rocha \& Soares, 2010) and computer literacy programs (Daquis et al., 2016).

Despite the availability of higher education community extension practice, there is inadequate literature on the evaluation of its impact 
or outcome. While there is no single assessment that gauges social impact of community programs (Felicen et al., 2014; O'loughlin et al., 1999; Peprah et al., 2017; Rocha \& Soares, 2010), most published studies focus on measuring impact on student development (Astin \& Sax, 1998; Astin et al., 2006; Lambright \& Lu, 2000; Llenares \& Deocaris, 2015; Llenares \& Espanola, 2015; Rhoads, 1998; Wang \& Rodgers, 2006). Moreover there are limited publications that investigate the long-term gains and social impact of extension programs (Felicen et al., 2014; Soska \& Butterfield, 2013). With the dearth of information on the broader social impact of higher education extension on communities and residents served, monitoring behavioural data can provide a useful guide for extension workers in preparing cost-effective programs that would have the highest societal value. Hence, this study aims to present an approach in evaluating community outreach efforts that focus on the perceived changes in attitude, behaviour, and lifestyle of local community residents who have attended the community outreach program during the 6-year period, from extension program development to outcomes, to the assessment of the outcomes.

\section{Description of the Outreach Program}

The outreach program described in this study are the community projects of the Technological Institute of the Philippines (T.I.P.), QuezonCity,Philippines.Afterconsultation with thelocalgovernment, the projects were designed to address the identified needs of the community and to provide support for community empowerment. Various academic departments and offices collaborated to implement the following education-training projects:

1. Livelihood and skills training project

2. Health-related education project

3. Computer literacy training project

Barangay Mangga (Barangay is a Filipino term for "local village"), an economically-disadvantaged community, is an adopted community of the school since 2008. The village is geographically adjacent to the school grounds and belongs to the informal settler sector in Quezon City. 


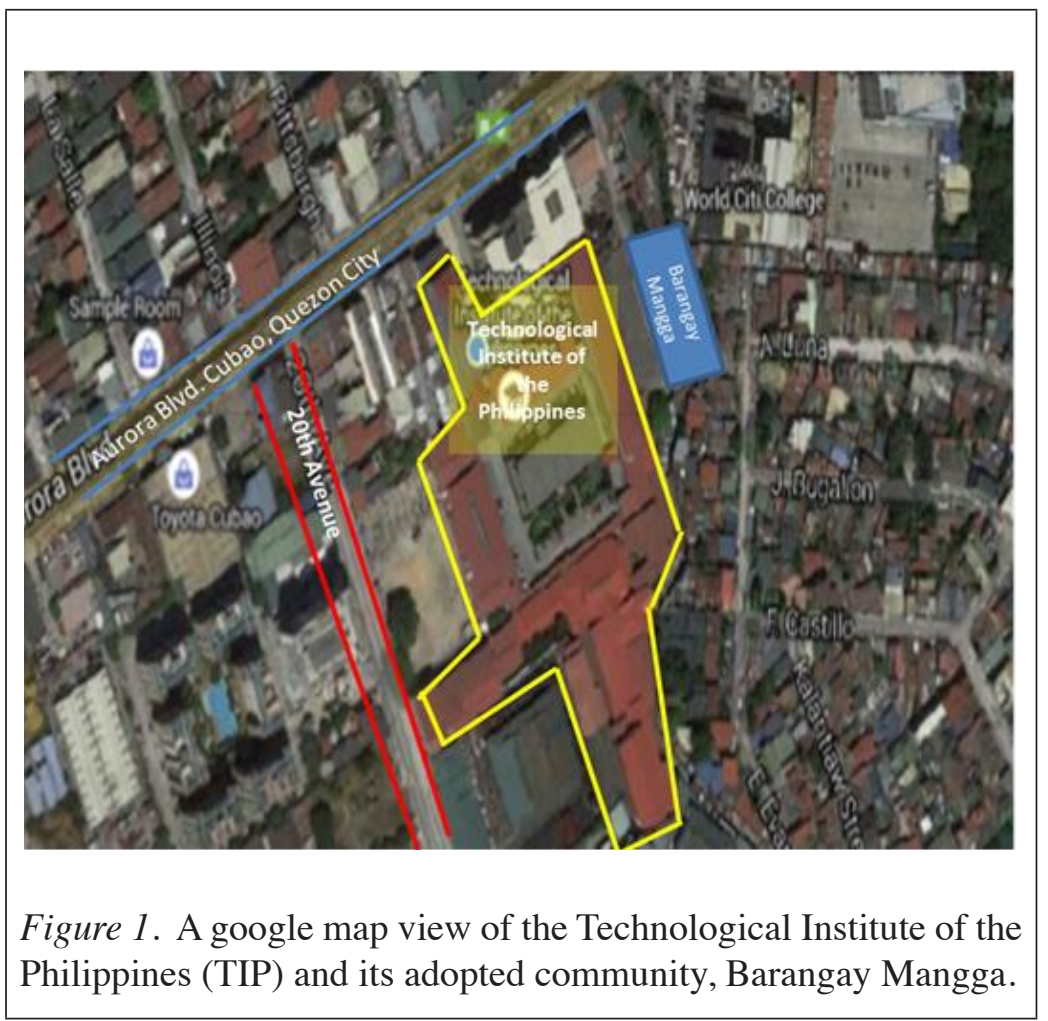

It is observed that some of houses were built along the walls of the school. Many residents of the community have been faced with problems of not only underemployment but also unemployment.

College faculty members initiated a series of meetings with local government officials and community representatives of Barangay Mangga in March 2009. The meeting entailed cooperation between academe and the community. The faculty team also administered a needs assessment to 70 residents to identify and prioritize the community development needs that will be addressed by the extension in this study. Livelihood training, family planning, financial literacy, health education, skills training, and computer literacy emerged as the most pressing needs of the community.

The process flow for the development and implementation of the extension program is presented in Figure 2. 


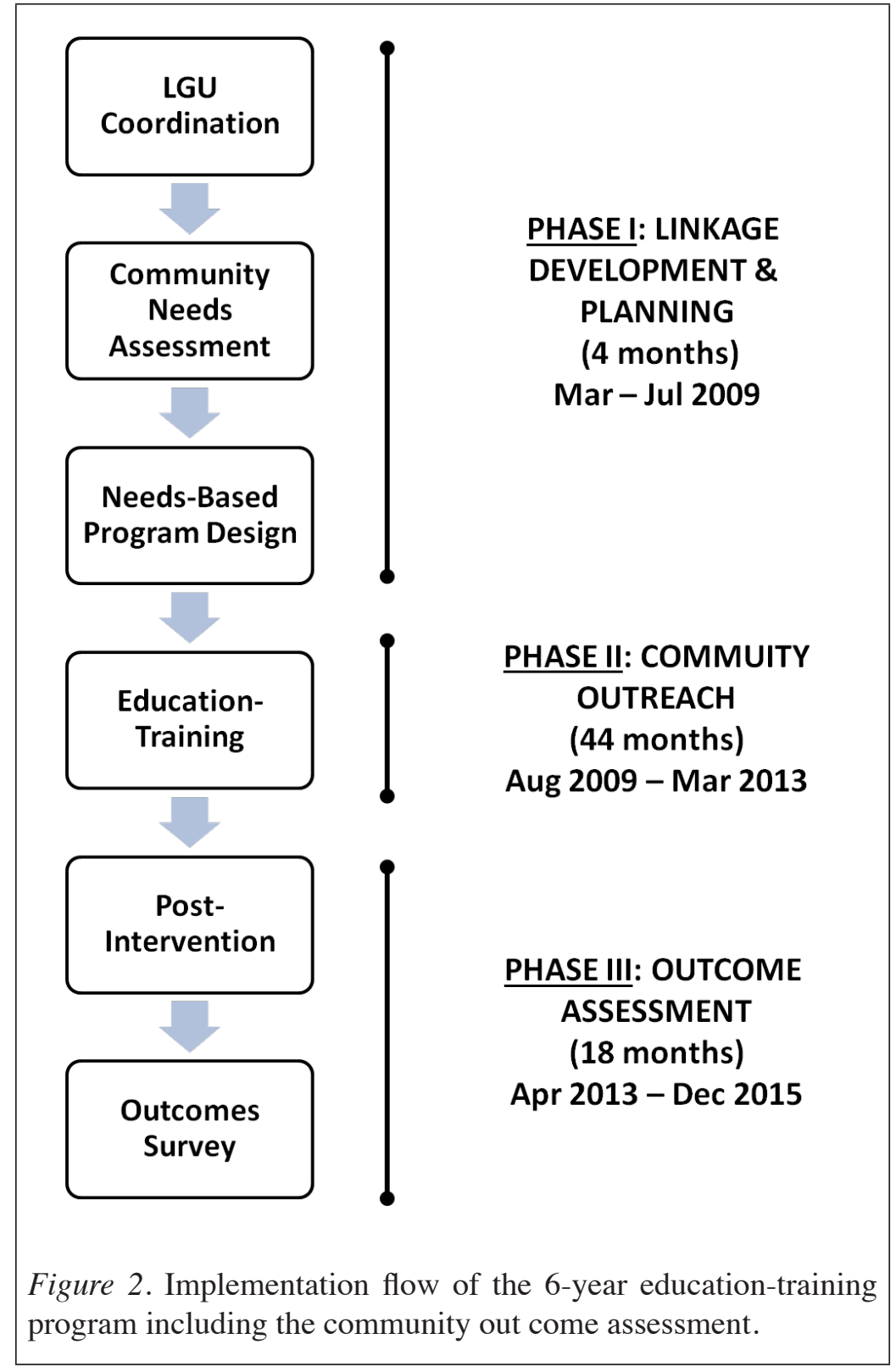

From May 2009 till June of the same year, the Social Orientation and Community Involvement Program (SOCIP) office led the design of the community education-training program based on the needs assessment survey. The different academic departments, namely, the Industrial Engineering, Computer Engineering, 
Electrical Engineering, Electronics Engineering, Business Education and Information System, and the Physical Education Department contributed to the planning of the extension program.

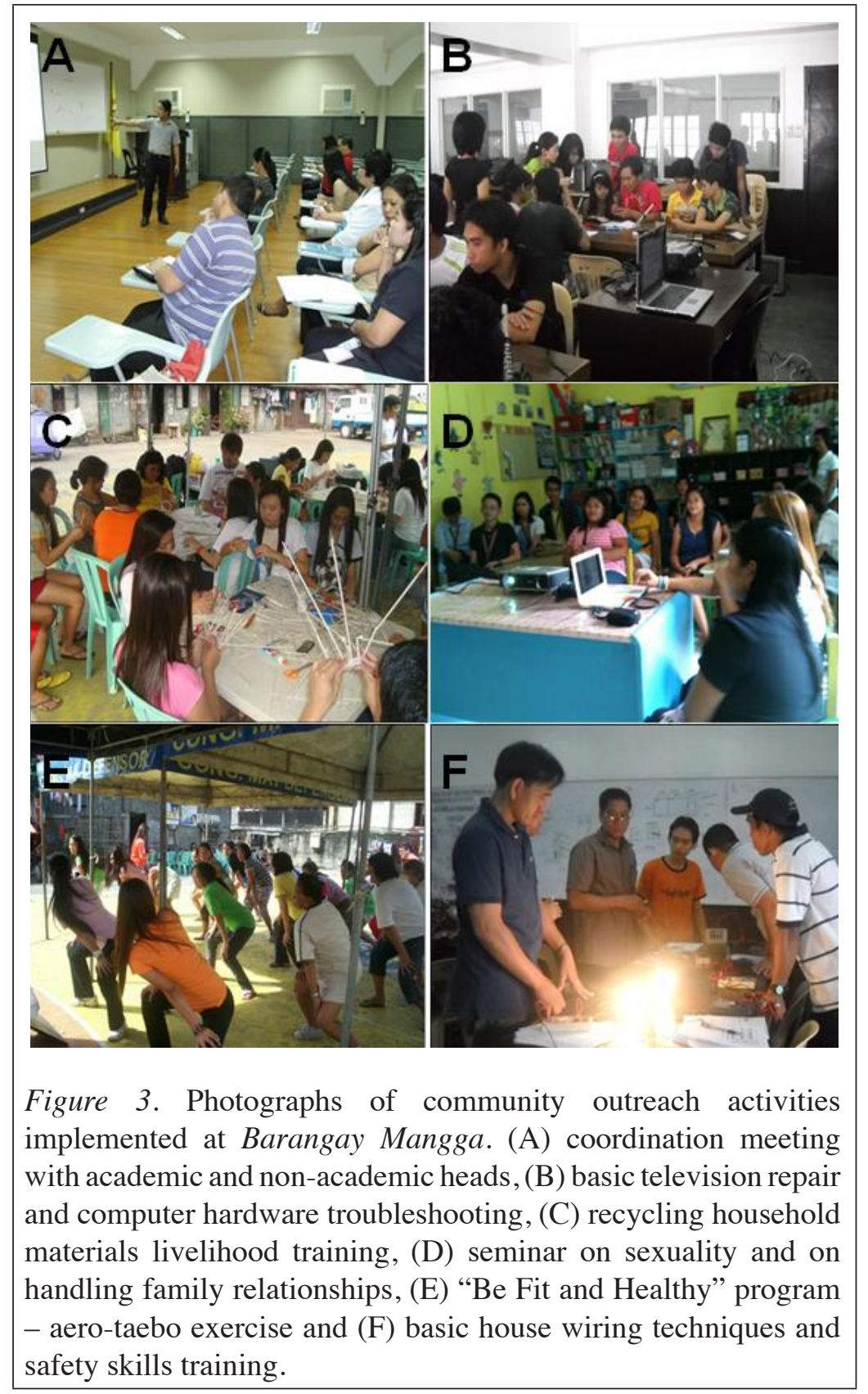


Table 1

Components of the Education-training Program for the Adopted Community as Implemented by Various Departments and Offices of the Technological Institute of the Philippines

\begin{tabular}{|c|c|c|c|}
\hline Departments & Description & $\begin{array}{l}\text { Community } \\
\text { Needs } \\
\text { Addressed }\end{array}$ & Duration/Date \\
\hline IE & $\begin{array}{l}\text { Eco-bag and } \\
\text { braided potholder }\end{array}$ & $\begin{array}{l}\text { Livelihood } \\
\text { training }\end{array}$ & $\begin{array}{l}8 \text { hours } \\
\text { Feb. } 9,2013\end{array}$ \\
\hline MAR-E & $\begin{array}{l}\text { Clean-up drive } \\
\text { "anti-dengue } \\
\text { campaign." }\end{array}$ & $\begin{array}{l}\text { Health } \\
\text { education }\end{array}$ & $\begin{array}{l}\text { Aug. 18-March } \\
\text { 19, } 2013\end{array}$ \\
\hline $\mathrm{CBE} / \mathrm{IE}$ & $\begin{array}{l}\text { Rag making and } \\
\text { financial literacy }\end{array}$ & $\begin{array}{l}\text { Livelihood } \\
\text { training }\end{array}$ & $\begin{array}{l}16 \text { hours } \\
\text { August } 10 \text { and } \\
17,2013\end{array}$ \\
\hline $\begin{array}{l}\text { SOCIP/MDS/ } \\
\text { GCC/IS }\end{array}$ & $\begin{array}{l}\text { Seminar on } \\
\text { sexuality } \\
\text { and human } \\
\text { relationships }\end{array}$ & $\begin{array}{l}\text { Health } \\
\text { education }\end{array}$ & $\begin{array}{l}16 \text { hours } \\
\text { January } 30 \text { and } \\
\text { February 13, } \\
2013\end{array}$ \\
\hline IS/SOCIP & $\begin{array}{l}\text { Computer literacy } \\
\text { (MS Word, } \\
\text { PowerPoint, and } \\
\text { Excel) }\end{array}$ & $\begin{array}{l}\text { Computer } \\
\text { literacy }\end{array}$ & $\begin{array}{l}8 \text { hours } \\
\text { February } \\
24,2013\end{array}$ \\
\hline PE & $\begin{array}{l}\text { "Be Fit and } \\
\text { Healthy" program } \\
\text { Aero-Taebo } \\
\text { exercise }\end{array}$ & $\begin{array}{l}\text { Health } \\
\text { education }\end{array}$ & $\begin{array}{l}3 \text { hours/day } \\
\text { October } 12- \\
\text { October } 30,2011\end{array}$ \\
\hline $\mathrm{ECE} / \mathrm{CPE}$ & $\begin{array}{l}\text { Basic computer } \\
\text { troubleshooting }\end{array}$ & Skills training & $\begin{array}{l}8 \text { hours } \\
\text { September 24, } \\
2011\end{array}$ \\
\hline IE & $\begin{array}{l}\text { Recycling } \\
\text { household } \\
\text { materials }\end{array}$ & $\begin{array}{l}\text { Livelihood } \\
\text { training }\end{array}$ & $\begin{array}{l}5 \text { hours } \\
\text { January 19, } 2012\end{array}$ \\
\hline IE & $\begin{array}{l}\text { Oplan Bantay } \\
\text { Kalusugan (Project } \\
\text { Health Watch) }\end{array}$ & $\begin{array}{l}\text { Health } \\
\text { education }\end{array}$ & $\begin{array}{l}8 \text { hours } \\
\text { September 24, } \\
2011\end{array}$ \\
\hline
\end{tabular}




\begin{tabular}{|c|c|c|c|}
\hline Departments & Description & $\begin{array}{l}\text { Community } \\
\text { Needs } \\
\text { Addressed }\end{array}$ & Duration/Date \\
\hline \multirow[t]{2}{*}{ CAS } & $\begin{array}{l}\text { Lecture on family } \\
\text { planning and } \\
\text { responsibility }\end{array}$ & $\begin{array}{l}\text { Health } \\
\text { education }\end{array}$ & $\begin{array}{l}\text { November 8, } \\
2010 \text { - March 4, } \\
2011\end{array}$ \\
\hline & $\begin{array}{l}\text { Beaded jewelry } \\
\text { making }\end{array}$ & $\begin{array}{l}\text { Livelihood } \\
\text { training }\end{array}$ & \\
\hline ECE & $\begin{array}{l}\text { Basic electronics } \\
\text { with television } \\
\text { troubleshooting } \\
\text { and repair }\end{array}$ & Skills training & $\begin{array}{l}16 \text { hours } \\
\text { August } 7-14 \text {, } \\
2010\end{array}$ \\
\hline SOCIP & Cooking lessons & $\begin{array}{l}\text { Livelihood } \\
\text { training }\end{array}$ & $\begin{array}{l}16 \text { hours } \\
\text { June } 7-14,2010\end{array}$ \\
\hline $\mathrm{EE}$ & $\begin{array}{l}\text { Basic House } \\
\text { Wiring Techniques } \\
\text { and } \\
\text { Safety }\end{array}$ & Skills training & $\begin{array}{l}\text { October 7- } \\
\text { November } 7 \text {, } \\
2009\end{array}$ \\
\hline SOCIP & $\begin{array}{l}\text { Common } \\
\text { kitchen project } \\
\text { "Indigenous } \\
\text { nutritional } \\
\text { food packages } \\
\text { promoted by the } \\
\text { entrepreneurial } \\
\text { poor" }\end{array}$ & $\begin{array}{l}\text { Livelihood } \\
\text { training }\end{array}$ & $\begin{array}{l}8 \text { hours } \\
\text { August 27, } 2009\end{array}$ \\
\hline
\end{tabular}

Abbreviations: IE, Industrial Engineering; PE, Physical Education Department; SOCIP, Social Orientation \& Community Involvement Program; MDS, Medical \& Dental Service Unit; GCC, Guidance \& Counselling Center; IS, Information System Department; CBE, College of Business Education; CPE, Computer Engineering Department; ECE, Electronics Engineering Department; EE, Electrical Engineering.

In July 2009 , the team presented the education-training program to the community leaders. The 44-month extension program commenced in August 2009. The community activities, such as livelihood training, health education, and computer literacy projects, were scheduled every Friday and Saturday. Academic de-loading was offered to the faculty members who were involved in the program. Figure 
4 presents some of the events during the community educationtraining program.

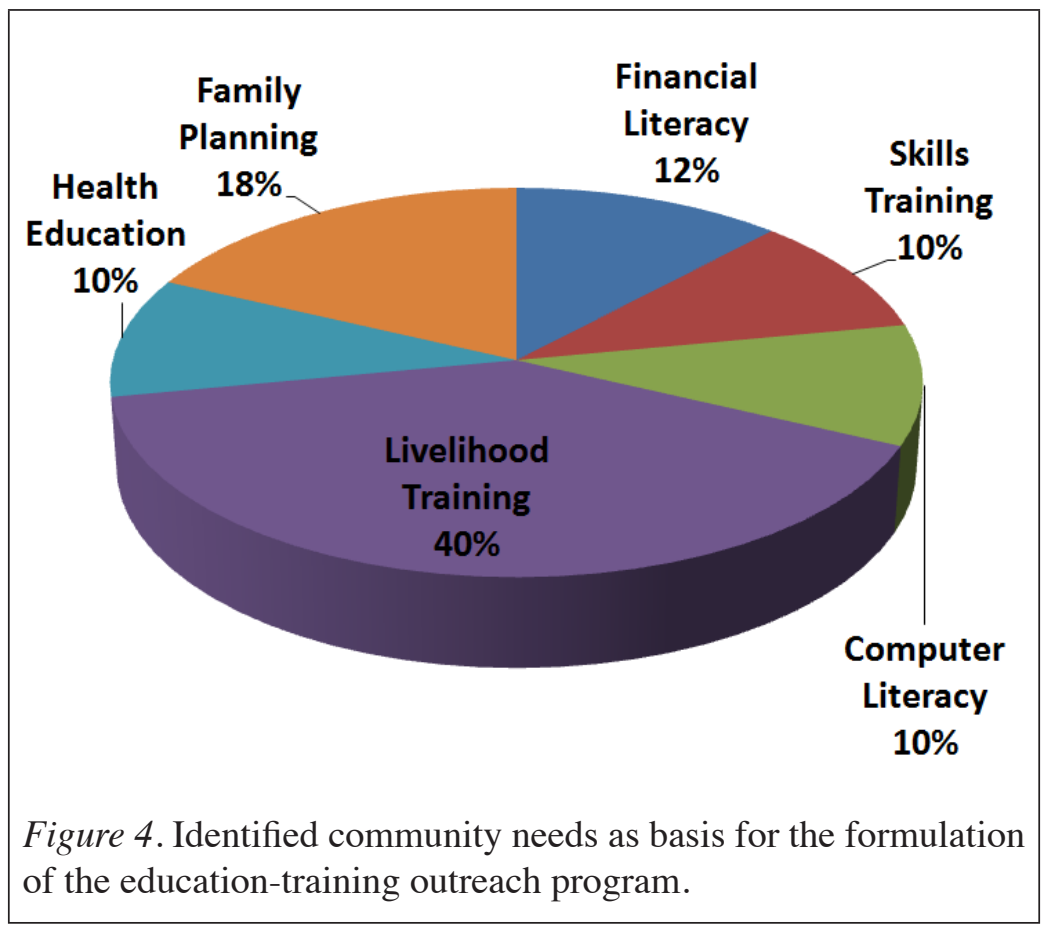

Individual face-to face interviews with key informant leaders and focus group discussions (FGDs) were facilitated to explore the community outcomes. This community activity resulted in the development of a survey tool. Eighteen (18) months after the last training program, the Community Outcome Scale instrument was administered to describe the perceived changes in knowledge, attitude, and lifestyle among the community residents.

\section{Theoretical Framework}

Community development is used both as a tool and process to address the challenges faced by the respective communities. The community development paradigm in the early 1970s focused on helping the poor at the community level within the context of existing social and economic structures. This model means that decisions and programs are defined by "outsiders" rather than by the local community members themselves. Being top-down and bureaucratic, many 
viewed this process as an efficient way of achieving specific national socio-economic goals (Morgan, 1965).

More recently, the bottom-up approach for community development has gained popularity (Dore \& Mars, 1981). Unlike the top-down model which is mainly defined by "outsiders," the bottom-up paradigm invokes the role of the local people in determining the type of intervention, priority setting, and implementation of the community programs. Also, this development paradigm concentrates on community empowerment (Flora \& Flora, 1993; Mendes, 2009) and operates at the grassroots and not on the policy level (Brocklesby $\&$ Fisher, 2003).

Community development is a process where government, nongovernment organizations, the volunteer sector, and even private corporations work together to empower communities economically, socially and even politically (Perkins et al.,2004). Some scholars view this as a means of mobilizing positive societal change by alleviating poverty, strengthening families and values, addressing specific social problems (e.g., increasing crime rate, etc.) and promoting democracy and inclusive development (Campfens, 1997; Paiva, 1977; York, 1984). According to Tan (2009), community development efforts benefit the most marginalized people to overcome imposed societal barriers. Overall, community development practice is often described as being distributive, participative, and focused on human development (Pandey, 1981). Schiele (2005) perceives community development as a collective problem-solving, self-directed and empowerment pursuit. Issues of drug addiction, for example, are handled not only by the community leaders and local government but also by the community members and families themselves in developing solutions. This model makes the public better able to further appreciate the process of community development.

Thus, the involvement of civic members represents an active component in community development. This as a driving force accrued from the collective interest among individuals and groups, provides a platform for cooperation among different players, e.g., community workers, government officials, educational leaders, nongovernment organization leaders and community people. 
The concept of empowerment is also an essential aspect of community development. Empowerment is the development of individuals' potential to gain control over their lives (Rappaport, 1981). This concept of self-determination allows an individual or groups of people to exercise their choices and propel decisions towards a desired set of actions or outcomes (Alsop \& Heinsohn, 2005). Within a community development viewpoint, residents are regarded as empowered, when they are mobilized and given opportunities to participate and decide on the nature of the public activities that they will be involved in for their personal good.

So far, the researchers have provided a brief discussion on the salient concepts of community development vis-à-vis a higher education program. The subsequent sections describe the methods of the study and discuss the key findings on the community outcomes.

\section{Participants}

\section{METHODOLOGY}

The study utilized a descriptive survey research design. Fifty-four community respondents were purposively selected for the study based on the following criteria: a) participated in any one of the community outreach activities, b) bona fide residents of Barangay Mangga, and c) consented to join the study.

\section{Survey Instrument}

Community Outcome Scale (COS), or Panukat ng Kinalabasan para sa Komunidad in Filipino, was used to measure the perceived changes in the knowledge, attitude, and lifestyle of the respondents based on the extended education-training programs . COS is composed of 26 questions in the Filipino language and uses the 4-point Likert scale (1, 'strongly disagree' to 4 , 'strongly agree'). The instrument has good internal reliability with Cronbach $\alpha=0.81$.

The COS tool specifically measures: a) 'knowledge' (10 questions associated with information on a particular set of skills, understanding a particular experience such as handling financial resources, family relationships, etc.), b) 'attitude' (6 questions related to the outlook in handling problems and conflict in relationships), and c) lifestyle' 
(10 questions associated with the improvement in the family's standard of living, such as the purchase of new property, increase in salary, and/or promotion at work). It took an average of 10 minutes to complete the tool.

The instrument was developed by a licensed psychometrician, based on the themes that emerged during the one-on-one interviews with key community leaders and FGDs with domain experts (community organizers, psychologist, and social workers). The tool was first given to 30 community residents before it was widely distributed amongst the respondents.

\section{Data Gathering}

The study protocol was approved by the Research \& Development Management Office (RDMO) and in consultation with the community leaders and residents. The survey tool was administered in groups in the barangay hall. Before the administration of the survey, all participants were introduced to the purpose and background of the study. They were then given the consent forms with further information.

\section{Data Analysis}

Shapiro-Wilk test was performed to examine if the data were normally distributed (Shapiro \& Wilk, 1965). Levene's statistics were computed to test the homogeneity of variances at $p<0.05$. One-way ANOVA with Posthoc analysis (SPSS version 17.0) was calculated to determine the effects of residents' participation in community outcomes: knowledge, attitude, and lifestyle. The frequency, mean and standard deviation were used to describe the profile and level of perceived changes in knowledge, attitude, and lifestyle of the respondents.

\section{RESULTS AND DISCUSSION}

\section{Profile of the Respondents}

Table 2 presents the demographic characteristics of the cohort. Noticeably, $93 \%$ of our respondents were female because most of the male members of the community were at work while the program was conducted. 
Table 2

Demographics of the Study Participants

\begin{tabular}{lcc}
\hline Variables & Frequency & Percentage \\
\hline Civil Status & & \\
Single & 12 & 22.2 \\
Married & 34 & 63 \\
Separated & 4 & 7.4 \\
Widowed & 4 & 7.4
\end{tabular}

Gender

Male

$4 \quad 7.4$

Female

50

92.6

Age

20 years old and below $\quad 5 \quad 9.3$

21 to 30 years old $\quad 18 \quad 33.3$

31 to 40 years old $\quad 11 \quad 20.4$

41 to 50 years old $\quad 9 \quad 16.7$

51 to 60 years old $\quad 8 \quad 14.8$

61 and above $\quad 3 \quad 5.5$

Family size

3 members and below $\quad 15 \quad 27.8$

4 to 6 members $\quad 35 \quad 64.8$

7 members and above $\quad 4 \quad 7.4$

Religion

$\begin{array}{lll}\text { Christian } & 52 & 96.3\end{array}$

$\begin{array}{lll}\text { Islam } & 2 & 3.7\end{array}$

Education

Elementary level

16.7

Elementary graduate

11.1

High school level

7.4

High school graduate

27.8

Vocational level

14.8

Vocational graduate

5.6

College level

9.3

College graduate

7.4 


\begin{tabular}{lcc}
\hline Variables & Frequency & Percentage \\
\hline Employment status & & \\
Unemployed & 28 & 51.8 \\
Employed & 28 & 51.8 \\
Entrepreneur & 8 & 14.8 \\
& & \\
Income & 37 & \\
Below USD 235 & 13 & 68.5 \\
USD 235 to USD 347 & 4 & 24.1 \\
USD 348 and above & & 7.4 \\
& & \\
Years of residency & 3 & 5.6 \\
Less than one year & 7 & 13 \\
1 to 5 years & 12 & 22.2 \\
6 to 10 years & 14 & 25.9 \\
11 to 15 years & 7 & 13 \\
16 to 20 years & 3 & 5.6 \\
21 to 25 years & 3 & 5.6 \\
26 to 30 years & 1 & 1.9 \\
31 to 35 years & 4 & 7.4 \\
36 years and above & & \\
& & \\
& &
\end{tabular}

\section{Perceived Changes in Knowledge, Attitude, and Lifestyle among Community Residents}

From the results, regular participants showed significantly higher scale scores for knowledge $(2.92 \pm 0.72)$, attitude $(2.96 \pm 0.62)$, and lifestyles $(2.71 \pm 0.65)$. One-way ANOVA revealed a significant difference between the three groups on knowledge outcomes $F(2$, $51)=24.76, p<0.01$ attitude outcomes $F(2,51)=27.00, p<0.01$ and lifestyle outcomes $F(2,51)=46.29, p<0.01$. Tukey's Posthoc analysis indicated that regular attendees benefited the most from knowledge outcomes.

The researchers also observed that the residents learned the importance of saving money and other resources, the value of family members' interpersonal relationships, and the importance of family planning, good housekeeping, and sanitation. They were also made aware of the more appropriate manner in preparing healthy food for their families. Furthermore, the women respondents realized that they could earn extra income even while staying at home through microentrepreneurship. The abovementioned outcomes are believed to have been attributed to the various relevant community education-training activities. 

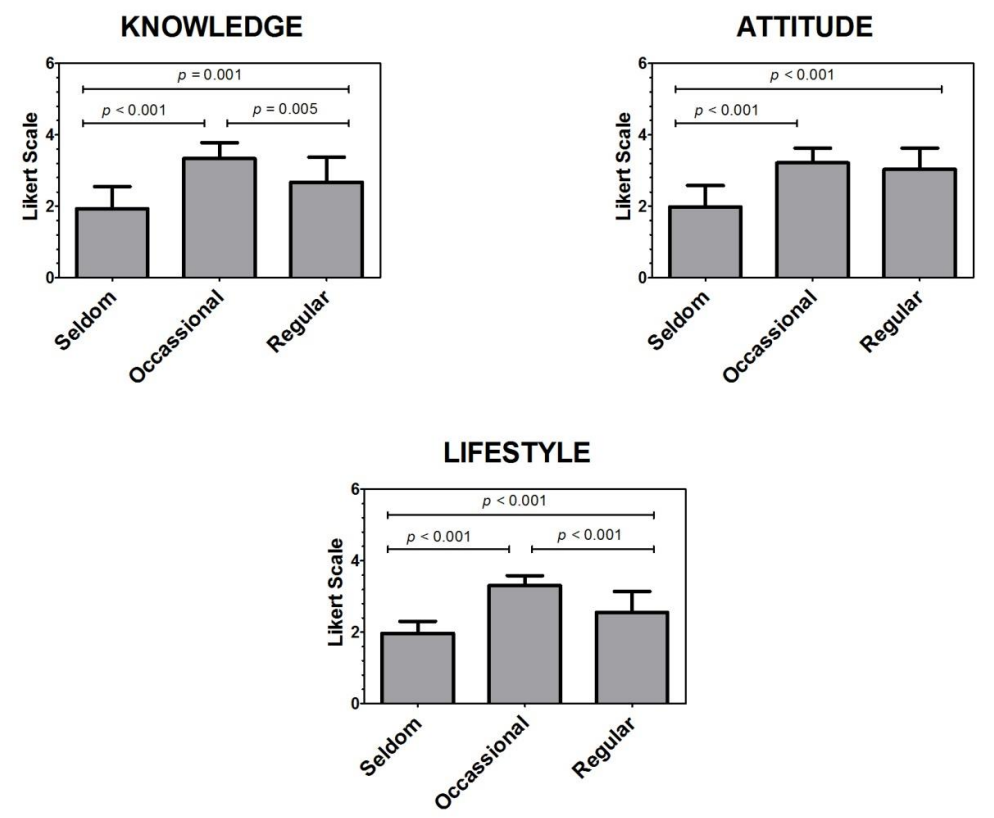

Figure 5. The perceived impact on the community residents 18 months after the delivery of the extension program based on the results of the Community Outcome Scale instrument. Shown above are perceived the impacts on knowledge [ $F$-value 24.76 ; 1 $d f(2,51)$; effect size $=0.49]$, attitude $[F$-value $27.00 ; d f(2,51)$; effect size $=0.52]$ and lifestyle $[F$-value $46.29 ; d f(2,51)$; effect size $=0.64]$. The degrees of participation are indicated as follows: seldom (attendance in 1-2 programs), occasional (participation in 3-6 programs) and regular (participation in all the education and training programs conducted during the study period).

Noteworthy outcomes on attitudes were observed in regular and occasional participants. The participants appeared to have a more positive outlook on life after attending the livelihood programs. The livelihood programs focused on how to prepare and sell snack foods and doormats. As the respondents learned to manage their resources (money, time, etc.) more conscientiously, they also reported earning additional income.

Furthermore, the attendees reported that they are more capable of maintaining harmonious relationships after the implementation of 
the community extension programs. They also perceived that they could handle the personality differences among the people whom they regularly dealt with, like family members, relatives, and neighbours.

The regular attendees also described the improvement in their lifestyle. With the additional income from the livelihood projects, several respondents reported to have purchased new appliances, primarily, television sets, and were able to donate more money to the community church. There was one attendee who disclosed having helped a neighbor pay for his/her medical expenses.

Overall, this study suggests that the rate of participation in the extension program is critical in bringing the benefits to the families in the community. Their attendance may be an indicator of life-long learning and the aspiration to improve their quality of life. It may also serve as an avenue to express ideas and work collaboratively with their neighbors (Chavis \& Wandersman, 1990; Perkins \& Long, 2002). According to some studies, residents' participation in community projects brings positive improvements on community awareness, neighboring (Perkins, Brown, \& Taylor, 1996; Unger \& Wandersman, 1985), community contentment (Perkins et al., 1990) and other positive communal bonds (Perkins et al., 1996).

In summary, this research provides some insights to future inquiries on developing tools to measure community outcomes or impact. It is noteworthy that sustainability of community extension programs does not depend entirely on sponsors and funders, but mainly on the responsiveness of the community and the stakeholders' approach towards community empowerment through the actions of the delivering institution. Given the positive attitudes of Filipinos despite poverty, future studies may also explore the characteristics of a resilient community.

\section{LIMITATIONS OF THE STUDY}

The researchers did not focus on family spending and employment as indicators of community outcomes, but instead, delved into the social and personal variables on a broader context. With regards to the methodology, validation of the learned skills, e.g., tests to 
verify computer literacy, before and after the training programs which can control the learning profile of the community residents are warranted.

\section{REFERENCES}

Alsop, R. A., \& Heinsohn, N. (2005). Measuring empowerment in practice: Structuring Analysis and framing indicators. World Bank Policy Research Working Paper, 3510. Washington, DC.

Astin, A. W., \& Sax, L. J. (1998). How undergraduates are affected by service participation. Service Participation, 39(3), 251.

Astin, A. W., Vogelgesang, L. J., Ikeda, E. K., \& Yee, J. A. (2000). How service learning affects students. Higher Education. Retrieved from https://heri.ucla.edu/PDFs/HSLAS/HSLAS. PDF

Bonye, S. Z., Thaddeus, A. A., \& Owusu-Sekyere, E. (2013). Community development in Ghana: theory and practice. European Scientific Journal, 9(17),79-101. Retrieved from https://eujournal.org/index.php/esj/article/viewFile/ $1159 / 1175$

Brocklesby, M. A., \& Fisher, E. (2003). Community development in sustainable livelihoods approaches-an introduction. Community Development Journal, 38(3), 185-198.

Campfens, H. (1997). Community development around the world: Practice, theory, research, training: University of Toronto Press.

Chavis, D. M., \&, \& Wandersman, A. (1990). Sense of community in the urban environment: A catalyst for participation and community development. Am J Community Psychol, 18, 5582.

Checkoway, B. (1991). Six strategies of community change. Jerusalem: The Hebrew University.

Cleary, L. S. A. B. (2006 ). The influence of service learning on students' personal and social development. College Teaching, 54(4), 307-319.

Daquis, M.A.,Flores, N.A., \& Plandez,R.Z.(2016). Implementation of extension project of radiologic technology department in one Barangay of San Jose, Batangas, Philippines. Asia Pacific Journal of Education, Arts and Sciences, 3(3), 109115. 
Dore, R. A., \& Mars, Z. (1981). Community developoment. London : Croom Helm.

Felicen, S. S., Mendoza, E. O., \& Buted, D. R. (2014). Impact of Hotel and restaurant management livelihood program to the beneficiaries in one of the university adapted communities. International Journal of Academic Research in Progressive Education and Development, 3(2), 125-136.

Flora, C. B. A., \& Flora., J. L. (1993). Entrepreneurial social infrastructure: A necessary ingredient. Annals ofthe American Academy of Political and Social Sciences, 539, 48-58.

Lambright, K. T., \& Lu, Y. (2000). What impacts the learning in service learning? An examination of project structure and student characteristics. Journal of Public Affairs Education, $15(4), 425-444$.

Llenares, I. I., \& Deocaris, C.C. (2015). Motivations for volunteerism among filipino college students. International Journal of Education and Research, 3(2), 599-610.

Llenares, I. I., \& Espanola, M. A. (2015). Does involvement in community service predicts student development? Paper presented at the Proceedings of Academics World 12th International Conference, Singapore.

Madan, R. (2007). Demystifying outcome measurement in community development: Joint Center for Housing Studies of Harvard University.

Markus, G. B., Howard, J. P., \& King, D. C. (1993). Notes: Integrating community service and classroom instruction enhances learning: Results from an experiment. Educational Evaluation and Policy Analysis, 15(4), 410-419.

Mendes, P. (2009). Teaching community development to social work students: A critical reflection. Community Development Journal, 44(2), 248-262.

Morgan, L. S. (1965). Community development: Observation around the world. American Journal of Public Health and the Nations Health, 55(4), 607-612.

O'loughlin, J. L., Paradis, G., Gray-Donald, K., \& Renaud,L. (1999). The impact of a community-based heart disease prevention program in a low-income, inner-city neighborhood. American Journal of Public Health, 89(12), 1819-1826.

Paiva, J. F. (1977). A conception of social development. Social Development Issues, 15(2), 327-328-336. 
Pandey, R. S. (1981). Strategies for social development: An analytical approach. In J. F. Jones, \& R. S. Pandey (Eds.), Social development: Conceptual, methodological and policy issues. Delhi. Macmillan India (pp. 34-49).

Peprah, P., Kyiyaga, E. M., Afful, H., Abalo, E. M., \& AgyemangDuah,W.(2017).Doesthe Ghanaianlivelihoodempowerment against poverty programme lead to an increase in household productive livelihood assets? Analysing the Ashanti scenario. Cogent Social Sciences, 3(1), 1298174.

Perkins, D. D., Brown, B. B., \& Taylor, R. B. (1996). The ecology of empowerment: Predicting participation in community organizations. Journal of Social Issues, 52, 85-110.

Perkins, D. D., Crim, B., Silberman, P., \& Brown, B. B., (2004). Community development as a response to community-level adversity: Ecological theory and research and strengthsbased policy. In KI Maton, CJ Schellenbach, BJ Leadbeater, BJ and AL Solarz, AL (Eds.), Investing in children, youth, families, and communities: strengths-based research and policy. Washington, DC: American Psychological Association.

Perkins, D. D., \& Long, D. A. (2002). Neighborhood sense of community and social capital: A multi-level analysis. In A. Fisher, C. Sonn, \& B. Bishop (Eds.), Psychological sense of community: Research, applications, and implications. New York: Plenum (pp. 291-318).

Perkins, D. D., Florin, P., Rich, R. C, Wandersman, A., \& Chavis, D. M. (1990). Participation and the social and physical environment of residential blocks: Crime and community context. Am J Community Psychol, 18, 83-115.

Rappaport, J. (1981). In praise of paradox: A social policy of empowerment over prevention. Am J Community Psychol, 9(1), 1-26.

Rhoads, R. A. (1998). In the service of citizenship: A study of student involvement in community service. Journal of Higher Education, 277-297.

Rocha, R., \& Soares, R. R. (2010). Evaluating the impact of community $\square$ based health interventions: evidence from Brazil's family health program. Health Economics, 19(S1), 126-158.

Schiele, J. J. H. (2005). Maggie Lena Walker and African American community development. Affilia, 20(1), 21-28. 
Shapiro, S. S., \& Wilk, M. B. (1965). An analysis of variance test for normality (complete samples). Biometrika, 52(3/4), 591611.

Soska, T., \& Butterfield, A. K. J. (2013). University-community partnerships: Universities in civic engagement: Routledge.

Tan, A. (2009). Community development theory and practice: Bridging the divide between 'micro'and 'macro'levels of social work. North American Association of Christian in Social Work. Indianapolis Indiana. Retrieved from https://www.nacsw.org/Publications/Proceedings2009/ TanACommunity.pdf

Unger, D. G., \& Wandersman, A. (1985). The importance of neighbors: The social, cognitive, and affective components of neighboring. Am J Community Psychol, 13, 139-170.

Wang, Y., \& Rodgers, R. (2006). Impact of service-learning and social justice education on college students' cognitive development. Journal of Student Affairs Research and Practice, 43(2), 518-539.

York, A. S. (1984). Towards a conceptual model of community social work. British Journal of Social Work, 14(3), 241-255. 